\title{
Physicomechanical Characterization of Basement Rocks for Construction Aggregate: A Case Study of Kajuru Area, Kaduna, Nigeria
}

\author{
A.G Amuda ${ }^{1}$, O.A.U. Uche ${ }^{1}$ and A.K Amuda ${ }^{2}$ \\ ${ }^{I}$ Civil Engineering Department, Bayero University Kano \\ ${ }^{2}$ Department of Geology, Ahmadu Bello University Zaria
}

\begin{abstract}
This study evaluates the physical, mechanical and in-situ properties of the rock aggregates in Kajuru, Kaduna State, Nigeria as sources of aggregate for construction purpose. The uniaxial compressive strength was determined by using Universal Testing Machine to crush cored samples and Schmidt rebound number by Schmidt hammer apparatus. While the engineering destructive tests were carried out on aggregates using various apparatus. $\mathrm{Na}_{2} \mathrm{SO}_{4}$ solution was used for soundness test and glass jar for determination of specific gravity. The results indicate that specific gravity ranges from 2.48 to 2.88 , the moisture content of samples are within $2 \%$. The UCS ranges from 95.76Mpa to 169.70Mpa while the Schmidt rebound number ranges from 29.4 to 35.3. Comparing the Los Angeles abrasion, impact and crushing value obtained from the laboratory destructive test with the B.S standards, most of the rock can be used for construction works. The results also indicate that there is direct proportional relationship between compressive strength with Schmidt rebound number and specific gravity. Inverse relationship exists between moisture content with specific gravity and compressive strength. The physical and geotechnical properties were found to be dependent on the chemical and petrographic characteristics of the rock.
\end{abstract}

Keywords: Basement rocks; compressive strength; destructive test; Moisture content; Specific gravity

\section{Introduction}

This paper exhibit the geotechnical and physical properties of rock as the second part of the research on Characterization of Basement Rocks in Kajuru area, Kaduna, Nigeria for Construction Aggregate. Kaduna is located on a basement rock that is widely used as construction materials for highways, bridges, dams, rail tracks and buildings. The excessive excavation of river sand is becoming a serious environmental problem (Jayawardena and Dissanayake, 2008) that leads to failure of river banks, lowering of river beds, damages to bridge foundations and other structures situated closer to the rivers. Similar trend is obtainable in northern Nigeria. Therefore rocks are also quarried for manufacture of quarry dust and are used as sand replacement for construction purposes and moulding of bricks. They are also used as granite and marble for production of magnificent walls, floor tiles and grandeur kitchen tops etc. In the various ways rock aggregates are used, they are exposed to a variety of stresses, and the response of the structure in which it is used will largely depend on the properties of the aggregate. It needs to resist heavy loads, high impacts and severe abrasion, and it needs to be durable in the prevailing environmental condition (Egesi and Tse, 2012).

This study was initiated from the observation that there are variations in properties and strength of rock and aggregate obtained from one geological location to the other. Therefore it is imperative to systematically characterize aggregates obtained from this area and evaluate factors that control the compressive strength of rock in order to develop practical quality-control specifications and ease optimum aggregate selection. The present study aims to highlight the basic engineering properties of aggregates source rock and integrate factors controlling them from this area.

\section{Materials and Methods}

Gamin76 (GPS) was used to survey the drill holes locations and their coordinates were recorded in the field work book. Cored rocks were obtained from 12 different drills holes spread across the research area at depth ranges from $12 \mathrm{~m}$ to $15 \mathrm{~m}$. Samples collected at $5 \mathrm{~m}$ depth intervals were placed in polythene bag which were accurately labelled for uniaxial compressive strength test. Large boulders were obtained from rock outcrops in situ and these outcrops were crushed into smaller sizes by local crusher to determine the physical properties.

Specific gravity and water absorption rate were measured using weight balance, oven and glass jar. Destructive test of impact and crushing value was carried out using their apparatus. Los Angeles abrasion test was done with abrasion testing machine while $\mathrm{Na}_{2} \mathrm{SO}_{4}$ solution was used for soundness test. Bulk samples taken from the specimens were also cut into blocks for Schmidt hammer test. 


\subsection{Uniaxial Compressive Strength}

\section{Results and Discussion}

The aim of this test is to determine the unconfined (uniaxial) compressive strength of rock specimens of cylindrical form. The test is mainly intended for use in rock strength assessment and classification of intact rock. ASTM Standard Test Method D2938-80 was used for the test. The specimens were loaded continuously at a constant stress rate till failure occurs and the value recorded. The average value ranges from $95.76 \mathrm{Mpa}$ to $169.70 \mathrm{Mpa}$. Generally, rock strength result reveal moderate values when compared to the standard range values of $80 \mathrm{Mpa}$ to $250 \mathrm{Mpa}$ for fresh metamorphic rocks such as gneiss (Deere and Miller, 1966).

\subsection{Schmidt Rebound Number}

The rebound value of the Schmidt Hammer is used as an index value for the intact strength of rock material, but this low cost and non-destructive test is also used to give an indication of the compressive strength of rock material. The value of the test is recorded after the hammer is released by it spring against the rock surface and the average value ranges from 29.4 to 35.3. Generally, the rebound number $(\mathrm{N})$ is corresponding with the UCS value.

\subsection{Specific Gravity of Rock Aggregate (SG)}

The specific gravity (SG) of all the samples tested is within the standard range. The result ranges from 2.48 (Porphyritic Granite) to 2.88 (Banded Gneiss). A rock of high quality often poses good specific properties. Low SG value for porphyritic granite (06) and Granite Gneiss (03) was as a result of fracture that might contain water and alteration of feldspar. Banded gneiss (11) has the highest specific gravity of 2.88 due to the fine texture and closely packed minerals. However most of them still fall within heavy weight aggregate as average specific gravity of rocks vary from 2.6 to 2.8 (Shetty,2005).

\subsection{Water Absorption Rate of Rock Aggregate}

Generally the water absorption rates for all the samples are below $2 \%$. Granite Gneiss (03) gives little high value than other rocks due to presence of micro cracks while Granite gneiss (07) contains weathered. Among the igneous rock, porphyritic granite (05 and 06) absorbs more water than others. Mohammad et al (2008 cited khan 2004) specified maximum limit of $2 \%$ for water absorption.

\subsection{Impact Value of Rock Aggregate (AIV)}

Porphyritic granite (06) had the lowest impact value of $42 \%$ and followed by $32 \%$ for porphyroblastic gneiss (08). This is a result of the platy (biotite cleavage) nature of some minerals in the rock sample. Some of the felsic mineral are also severely altered, they contain lesser percentage of quartz mineral. The best AIV is porphyritic granite (05) with $23 \%$ followed by porphyritic granite (12) with $25 \%$, they are only slightly altered. The IS 283-1970 code specifies that aggregate impact value shall not exceed $45 \%$ by weight for aggregate used for concrete other than wearing surface and $30 \%$ by weight for concrete used for wearing surfaces, such as runways roads and pavement. The fine grains of granite gneiss (03) are massive in nature and when at dry stage remain compacted.

\subsection{Crushing Value of Rock Aggregate (ACV)}

The values of relative measure of resistance of an aggregate to crushing when it is subjected to compressive forces of aggregate took the same trend as aggregate impact value; there will be a positive correlation between these two characteristics. Porphyritic granite (05), banded gneiss (11) and porphyritic granite (12) gave a better ACV that was corresponding to their AIV while porphyritic granite (06) and porphyroblastic gneiss gave a poorer value. According to Shetty (2005), the crushing value of aggregate is restricted to $30 \%$ for concrete used for roads and pavements and $45 \%$ may be permitted for other structures.

\subsection{Los Angeles Abrasion Value of Rock Aggregate (LAAV)}

The Los Angeles abrasion value ranges from $21.12 \%$ to $37.01 \%$. Porphyritic granite (05) has the best LAAV of $21.12 \%$ followed by porphyroblastic gneiss (08) while the lowest LAAV value is $37 \%$ (porphyritic granite 06). All the value are within safe limits for most construction work, the higher the depth the better the LAAV value. The maximum allowed LAAV of aggregates for sub-base is $50 \%$, base course is $40 \%$, and asphalt concrete is $35 \%$ and $16 \%$ for concrete aggregate (AASHTO T-96 section 904.03). The abrasion value should not be more than $30 \%$ for wearing surface and not more than $50 \%$ for concrete other than wearing surface (Shetty, 2005). 


\subsection{Soundness Value of Rock Aggregate}

The percentage value of soundness obtained from the test ranges from $1 \%$ to $4.5 \%$ against AASHTO T-104 recommendation of $10 \%$ for concrete works and $12 \%$ for base course (maximum). It was also observed that the depth does not have significant difference on the soundness test except for few cases. Granite gneiss (03) has the highest soundness loss with $4.5 \%$ followed by porphyritic granite (05). The entire aggregate sample has the ability to resist excessive changes in volume as a result of changes in physical condition. Shetty (2005) gave general guide of $18 \%$ maximum.

Table 1: Summary Of Engineering Characteristics

\begin{tabular}{|c|c|c|c|c|c|c|c|c|c|}
\hline \multirow[t]{2}{*}{ S/No } & \multirow[t]{2}{*}{ DESCRIPTION } & \multicolumn{8}{|c|}{ ENGINEERING PROPERTIES } \\
\hline & & w\% & SG & $\mathrm{S \%}$ & IV\% & CV\% & LOS\% & HM & UCS(mpa) \\
\hline 01 & Porphyroblastic gneiss & 0.77 & 2.54 & 1.5 & 30.7 & 34.5 & 29.0 & 29.2 & 136.8 \\
\hline 02 & Porphyroblastic gneiss & 0.69 & 2.59 & 1.0 & 29.3 & 31.6 & 27.1 & 31.5 & 128.1 \\
\hline 03 & Granite gneiss & 1.67 & 2.49 & 4.5 & 28.6 & 31.1 & 25.3 & 39.2 & 137.5 \\
\hline 04 & Leucocratic granite & 0.79 & 2.65 & 2.5 & 31.0 & 35.5 & 33.2 & 27.9 & 140.7 \\
\hline 05 & Porphyritic granite & 0.82 & 2.51 & 3.0 & 22.6 & 29.3 & 21.1 & 35.9 & 104.1 \\
\hline 06 & Porphyritic granite & 1.28 & 2.48 & 1.5 & 42.0 & 42.6 & 37.0 & 28.2 & 95.76 \\
\hline 07 & Granite gneiss & 1.50 & 2.60 & 1.0 & 31.8 & 31.2 & 25.8 & 34.4 & 142.0 \\
\hline 08 & Porphyroblastic gneiss & 0.83 & 2.64 & 1.0 & 32.6 & 39.1 & 21.9 & 35.1 & 123.3 \\
\hline 09 & Boitite granite & 0.74 & 2.63 & 1.5 & 27.2 & 32.2 & 24.8 & 31.1 & 129.3 \\
\hline 10 & Porphyroblastic gneiss & 0.66 & 2.66 & 1.0 & 29.8 & 31.9 & 26.9 & 30.3 & 124.0 \\
\hline 11 & Banded gneiss & 0.58 & 2.88 & 1.0 & 28.9 & 29.4 & 26.0 & 35.3 & 169.7 \\
\hline 12 & Porphyritic granite & 0.62 & 2.67 & 1.5 & 24.9 & 30.3 & 22.3 & 32.1 & 159.1 \\
\hline
\end{tabular}

The test result of uniaxial compression strength test was used to establish a strength map (Fig. 1) with an inferred boundary. The lower strength of porphyritic granite (06) was as a result of the microcracks and it closeness to the river which as facilitate chemical weathering of the plutonic rock by hydrolysis. While the unexpected decrease in strength of porphyritic granite (05) could be as a result of mechanical drilling process that may have introduced micro fractures in the sample.

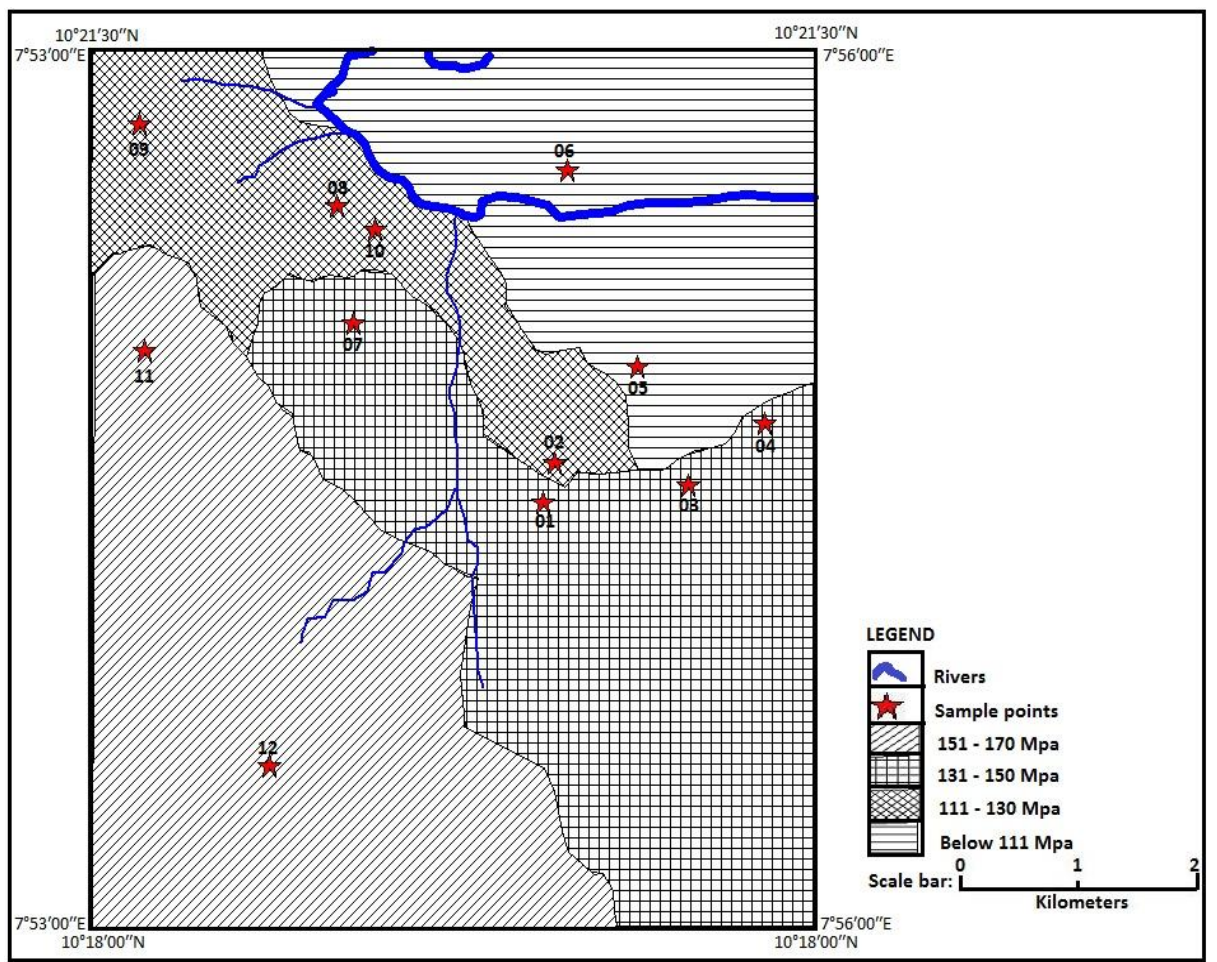

Fig. 1: Geotechnical map showing rock strength variations in the study area.

\subsection{Correlation Analysis}


A need to establish and measure the degree and strength of relationship that exist between two data or parameters obtained from these research was discerned with Pearson correlation coefficient as follows.

\subsubsection{Uniaxial Compression versus Schmidt Number}

In this work, positive correlation coefficient exist between $\mathrm{N}$ values and UCS, this indicate that $\mathrm{N}$ is related to UCS value. The higher the compressive strength of rock samples, the higher the rebound number (Fig. 2).

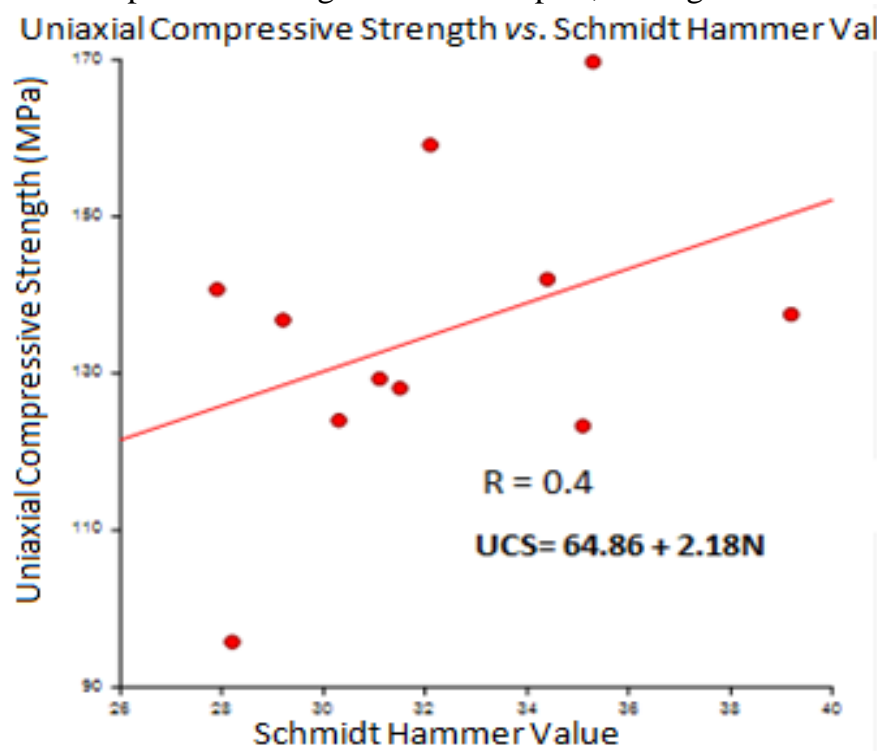

Fig. 2: Relationship between rebound Number and Compressive strength

\subsubsection{Uniaxial Compression versus Moisture Content}

The correlation diagram below shows a weak relationship between the moisture content and uniaxial compressive strength which might have result from negative contribution of microcracks, fracture and weathering (Fig. 3). Edet (1992) confirmed that weathering and structural defect (fracture/joint/microcracks) generally, will decrease the strength of material, accelerate the rate of alteration and increase the amount of saturation.

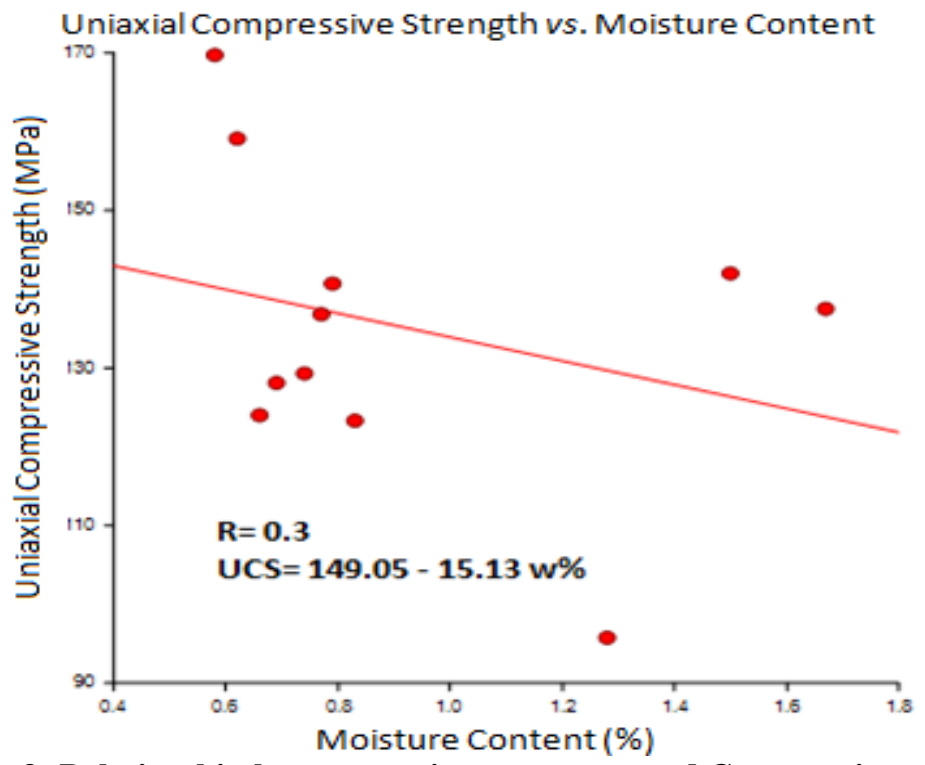

Figure 3: Relationship between moisture content and Compressive strength

\subsubsection{Uniaxial Compression versus Specific Gravity}

The relationship between the compressive strength and specific gravity was established. The diagram shows that the higher the compressive strength the higher the specific gravity (Fig. 4). This implies that heavy weight aggregates, without planes of weakness and fractures exhibit high compressive strength. 


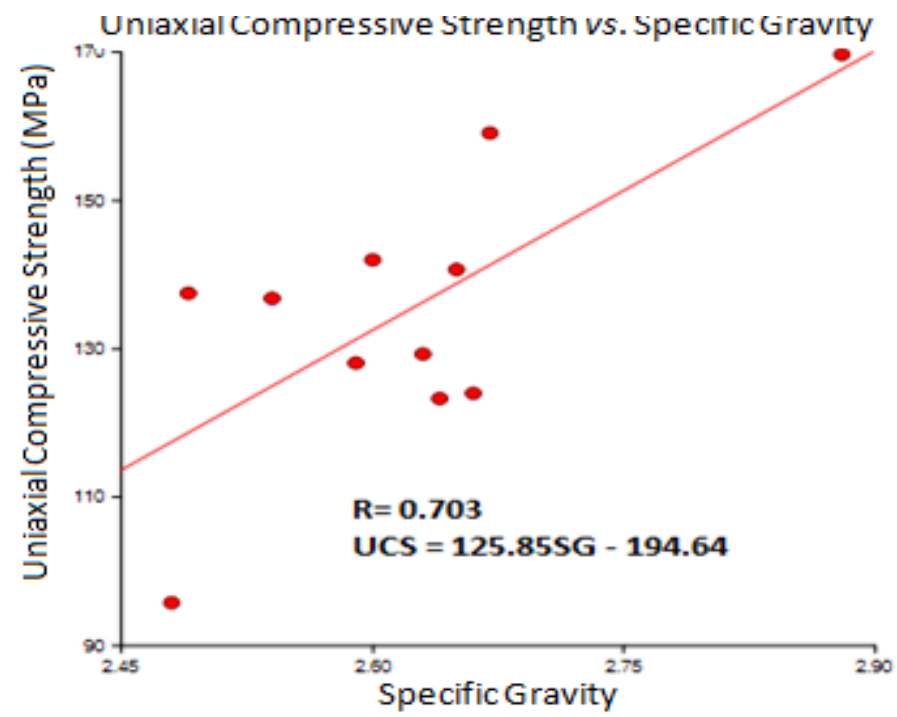

Figure 4: Relationship between Specific Gravity and Compressive strength

\subsubsection{Moisture content versus Specific Gravity}

Moisture content negatively correlated with specific gravity (Fig. 5) which inferred low specific gravity value for rocks with high water content. Normally aggregate of high porosity exhibit high water absorption rate and low specific gravity while intact aggregate has low water absorption rate and high specific gravity.

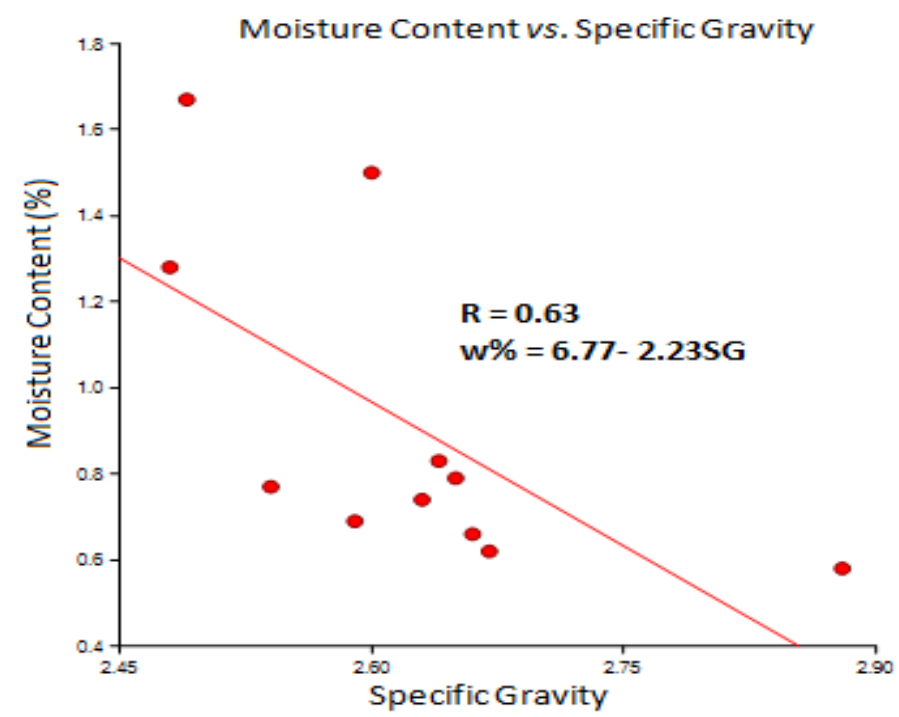

Fig. 5: Relationship between Specific Gravity and moisture content.

\section{Conclusion}

The study area is composed of Precambrian igneous (granite) and high grade regional metamorphic (gneiss) intact rocks which are densely packed. A practical approach has been presented for the evaluation of rock and aggregate from Kajuru local government of Kaduna state. The comprehensive characterization used in this study revealed the link between physico-mechanical properties of rock aggregate. Generally the rock is geotechnically stable and of economical quantity.

Uniaxial compressive strength (UCS) test plays a very significant role in rock engineering project, rebound hammer test can be used as a simple tool for quick assessment and suggest a preliminary value for UCS of rock quality in the study area and environs. The uniaxial compressive strength test has revealed that banded gneiss (11) and porphyritic granite (12) have the highest UCS which was also confirmed with Schmidt rebound number. Petrographical analyses have revealed banded gneiss (11) and porphyritic granite (5) which have performed better in all the engineering test possess less mica (biotite and muscovite) minerals.

The water absorption rate for this area is very adequate except for the rocks with microcrack and fracture which tend to absorb more water. The specific gravity for most of the rock samples are up to 2.6 which make them heavy weight rock. 
Comparing the impact and crushing value obtained from laboratory destructive test with standards, most of the rock can be used for most construction works like concrete embankments, foundations, concrete asphalt for highway and air- field pavement. Porphyritic granite (6) should be restricted for use in building construction. The Los Angeles abrasion and soundness value obtained from test carried out on the sample from the proposed quarry is within the allowable standard.

There is direct proportional relationship between Unconfined Compressive Strength versus Schmidt Hammer, Specific Gravity and inverse relationship between Moisture content versus Unconfined Compressive Strength, Specific Gravity.

It is recommended that suitable allowances be given in terms of water cement ratio for possible reduction in the strength of concrete because of mica content.

\section{References}

[1]. American Society For Testing And Materials ASTM .(1975).Special Procedure For Testing Soils And Rocks For Engineering Purposes, Technical Publication No. 479, 5th Edition.

[2]. American Society For Testing And Materials, ASTM.(1988). Test Method For Unit Weight And Voids In Aggregate. C127-84

[3]. American Association Of State Highway And Transportation Official, AASHTO.(2001). Specific Gravity And Absorption Of Coarse Aggregate. Washington DC. Technical Specification. No. T85.

[4]. Bloem,D.L. (1966). Significance Of Tests And Properties Of Concrete And Concrete-Making Materials, Soundness And Deleterious Substances, ASTM, STP,169A, ASTM International, West Conshohoken. P. 497-512.

[5]. British Standard Institute BS 812, Part 2. (1975). Specific Gravity And Absorption Of Coarse Aggregate.

[6]. British Standard Institute BS 812, Part 3. (1975). Method Of Determining Aggregate Crushing Value For Civil Engineering Structures.

[7]. Cargill, J.S. And Shakoor, A. (1990).Evaluation Of Empirical Methods For Measuring The Uniaxial Strength Of Rock.International Journal Of Rock Mechanics, Mineralogical Science, Volume 27: Pages 495-503.

[8]. Deere, D.U. And Miller, R.P. (1996).Engineering Classification And Index Properties For Intact Rocks. Tech Rep Air Force Weapons Lab, New Mexico, No AFNL-TR, 65-116.

[9]. Edet, A.E. (1992). Physical Properties And Indirect Estimation Of Micro Fracture Using Nigeria Carbonate Rock As Example. Engineering Geology, Volume 33, Pages 71-80.

[10]. Egesi, N Andtse, A.C. (2012). Engineering -Geological Evaluation Of Rock Materials From Bansara, Bamenda Massif Southeastern Nigeria, As Aggregates For Pavement Construction. Available From: Http://Journal.Sapub.Org/Geo. Volume 2(5): Pages 107-111

[11]. FHWA.(1991). Rock And Mineral Identification For Http://Www.Fhwa.Dot.Gov/Pavement/Pccp/Fhwahi91205.Pdf. 2013

[12]. Instrotek, Inc. (2000). Fine And Coarse Aggregate Absorption And Specific Gravity Determination Using The Aggplustm System. Available In :Http:// Instrotek.Com/Wordpress/Downloads/Aggplus/

[13]. Jayawardena, U.D.S. Anddissanayake, D.M.S. (2008). Identification Of The Most Suitable Rock Types For Manufacture Of Quarry Dust In Sri Lanka. Journal Of The National Science Foundation Of Sri Lanka. Volume 36, Number 3.

[14]. .Kahraman, S. (2001) Evaluation Of Simple Methods For Assessing The Uniaxial Compressive Strength Of Rock. Int. J. Rock Mech. Min. Sci., 38:981-994.

[15]. Masuda, K. (2001). Effects Of Water On Rock Strength In A Brittle Regime.Journal Of Structural

[16]. Mick, R.S., Laurence, C. And Peter G.F. (1985). Aggregates: Sand, Gravel And Crushed Rock Aggregates For Construction Purposes. Geological Society, Engineering Geology Special Publication Number 17.

[17]. Quiroga, P.N. (2003).The Effect Of Aggregate Characteristics On The Performance Of Portland Cement Concrete. Phd Dissertation, The University Of Texas At Austin, Austin, TX.

[18]. Robertson, E.C. (1955).Experimental Study Of The Strength Of Rocks, Bulletin Of Geological Society Of America, 66 Page $1275-$ 314.

[19]. Russ, W. (1957).The Geology Of Parts Of Niger, Zaria And Sokoto Provinces.Geological Survey Of Nigeria Bulletin (27).

[20]. Schmidt, E. (1951).A Non-Destructive Concrete Tester.Concrete, 59(8): Pages 34-35.

[21]. Shetty, M.S. (2005).Concrete Technology Theory And Practice (6 $6^{\text {th }}$ Edition).Chand And Company Limited, New Delhi.

[22]. Smith, M. R. And Collis, L. (2001). Aggregates - Sand, Gravel And Crushed Rock Aggregates For Construction Purposes (3rd Edition). The Geological Society London.Page 339.

[23]. Torabi, S. R. (2005). Reliability Of The Application Of Schmidt Hammer In Determination Of The UCS. Final Project Report, In Persian, Shahrood University Of Technology, Shahrood, Iran.

[24]. Torabi S.R., Ataei, M. Andjavanshir,M. (2010).Application Of Schmidt Rebound Number For Estimating Rock Strength Under Specific Geological Conditions.Journal Of Mining \&Environment Volume 1, Number2, Pages 1-8.

[25]. Wu, Y., Parker, F. Andkandhal, K. (1998). Aggregate Toughness/Abrasion Resistance And Durability/Soundness Tests Related To Asphalt Concrete Performance In Pavements. Transportation Research Board Record: 1638. 